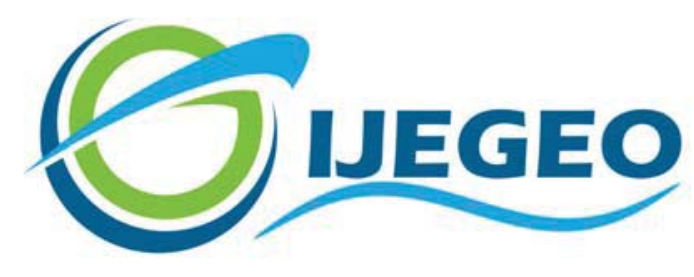

International Journal of Environment and Geoinformatics (IJEGEO) is an international, multidisciplinary, peer reviewed, open access journal.

\title{
Comparison of Advanced Oxidation Processes (Sonication, Fenton Reaction and Ozone-Based Processes) for Water Decolorization
}

\section{Başak SAVUN HEKIMOĞLU}

\author{
Chief in Editor \\ Prof. Dr. Cem Gazioğlu \\ Co-Editors \\ Prof. Dr. Dursun Zafer Şeker, Prof. Dr. Şinasi Kaya, \\ Prof. Dr. Ayşegül Tanık and Assist. Prof. Dr. Volkan Demir
}

Editorial Committee (June 2021)

Assoc. Prof. Dr. Abdullah Aksu (TR), Assit. Prof. Dr. Uğur Algancı (TR), Prof. Dr. Bedri Alpar (TR), Assoc. Prof. Dr. Aslı Aslan (US), Prof. Dr. Levent Bat (TR), Prof. Dr. Paul Bates (UK), İrşad Bayırhan (TR), Prof. Dr. Bülent Bayram (TR), Prof. Dr. Luis M. Botana (ES), Prof. Dr. Nuray Çağlar (TR), Prof. Dr. Sukanta Dash (IN), Dr. Soofia T. Elias (UK), Prof. Dr. A. Evren Erginal (TR), Assoc. Prof. Dr. Cüneyt Erenoğlu (TR), Dr. Dieter Fritsch (DE), Prof. Dr. Çiğgem Göksel (TR), Prof.Dr. Lena Halounova (CZ), Prof. Dr. Manik Kalubarme (IN), Dr. Hakan Kaya (TR), Assist. Prof. Dr. Serkan Kükrer (TR), Assoc. Prof. Dr. Maged Marghany (MY), Prof. Dr. Michael Meadows (ZA), Prof. Dr. Nebiye Musaoğlu (TR), Prof. Dr. Masafumi Nakagawa (JP), Prof. Dr. Hasan Özdemir (TR), Prof. Dr. Chryssy Potsiou (GR), Prof. Dr. Erol Sarı (TR), Prof. Dr. Maria Paradiso (IT), Prof. Dr. Petros Patias (GR), Prof. Dr. Elif Sertel (TR), Prof. Dr. Nüket Sivri (TR), Prof. Dr. Füsun Balık Şanlı (TR), Prof. Dr. Uğur Şanlı (TR), Duygu Ülker (TR), Prof. Dr. Seyfettin Taş (TR), Assoc. Prof. Dr. Ömer Suat Taşkın (TR), Assist. Prof. Dr. Tuba Ünsal (TR), Dr. Manousos Valyrakis (UK), Dr. İnese Varna (LV), Dr. Petra Visser (NL), Prof. Dr. Selma Ünlü (TR), Assoc. Prof. Dr. Oral Yağcı (TR), Prof. Dr. Murat Yakar (TR), Assoc. Prof. Dr. İ. Noyan Yılmaz (AU); Assit. Prof. Dr. Sibel Zeki (TR) 


\title{
Comparison of Advanced Oxidation Processes (Sonication, Fenton Reaction and Ozone-Based Processes) for Water Decolorization
}

\author{
Başak Savun-Hekimoğlu iD \\ Istanbul University, Institute of Marine Sciences and Management, 34134 VEFA Istanbul/Turkey
}

Received 21 Sept 2020 Accepted 10 Dec. 2020

* E-mail: basak.savun@istanbul.edu.tr How to cite: Savun-Hekimoğlu, B. (2021). Comparison of Advanced Oxidation Processes (Sonication, Fenton Reaction and Ozone-Based
Processes) for Water Decolorization. International Journal of Environment and Geoinformatics (IJEGEO), 8(2):166-171. doi. 10.30897/ ijegeo.797764

\begin{abstract}
The excessive use of azo dyes results in their discharge with the industrial wastewater effluents. Recent studies show that conventional wastewater treatment processes cannot remove these pollutants that are known to be toxic both to aquatic life and humans. Hence, the elimination of such pollution has lately been a primary environmental concern, and a variety of methods comprising of biological and chemical processes have been tested. Advanced oxidation processes are a promising option to remove these compounds completely while reducing their toxicity via mineralization. The aim of this study is to test several advanced oxidation processes for the decolorization of Remazol Brillant Blue R. Studied advanced oxidation processes are sonication, Fenton reaction, ozonation $\left(\mathrm{O}_{3}\right)$, ozonation and UV irradiation $\left(\mathrm{O}_{3} / \mathrm{UV}\right)$ and a hybrid process of ozonation UV irradiation and hydrogen peroxide $\left(\mathrm{O}_{3} / \mathrm{UV} / \mathrm{H}_{2} \mathrm{O}_{2}\right)$. The efficiencies of the processes are determined by decolorization and mineralization and found to be in the decreasing order of $\mathrm{O}_{3} / \mathrm{UV} / \mathrm{H}_{2} \mathrm{O}_{2}>$ Fenton $>\mathrm{O}_{3} / \mathrm{UV}>$ Ultrasound $>$ Ozone.
\end{abstract}

Keywords: Advanced Oxidation Processes, Fenton reaction, Ozonation, Photocatalysis; Ultrasound

\section{Introduction}

Advanced oxidation processes (AOPs) are known for their efficiency in removing refractory compounds such as azo dyes from water and wastewater. The efficiency of these processes depends on their capacity to generate hydroxyl radical $(\mathrm{OH} \bullet)$ which is the strongest known oxidant (Frontistis et al., 2017). The most common AOPs include sonication, Fenton reaction, ozonation $\left(\mathrm{O}_{3}\right)$, photocatalysis and their several combinations (Miklos et al., 2018; Krishnan et al., 2017; Tufail et al, 2020; Fast et al., 2017; Babu et al., 2017).

Sonication is the use of ultrasound waves to propagate the phenomenon called acoustic cavitation. Acoustic cavitation consists of three successive stages: i) nucleation, ii) bubble growth (expansion), iii) implosive collapse (Suslick, 1990). In the first stage, microbubbles are trapped in micro-crevices of small particles within the liquid form cavitational nuclei, where cavities are generated depending on the type and purity of the liquid. (Suslick, 1990; Peters, 1996). In the second stage, the microbubbles once formed grow and expand depending on the intensity of the applied sound, and when the intensity is too high, a small cavity may grow rapidly through inertial effects (Suslick, 1990). When the acoustic intensity is low, the cavity grows by rectified diffusion and lasts many more acoustic cycles before expansion (Suslick, 1990).

The third stage of cavitation occurs when the cavity is so overgrown that it can no longer absorb energy to sustain itself, and the surrounding liquid rushes in to lead to a violent implosion as a catastrophic collapse (Mason and Peters, 2002; Mason 1990; Suslick et al. 1990). At this point, the extremes of temperatures and pressures create an unusual environment or high-energy micro-reactors that enable molecular fragmentation of the entrapped gases in the collapsing cavities (Ince et al.,2001). The reactions of sonication are shown in the following equations (Ince et al., 2001; Lorimer and Mason, 1991; Fischer et al., 1986):

$$
\begin{aligned}
& \left.\left.\left.\mathrm{H}_{2} \mathrm{O}+\right)\right)\right) \rightarrow \cdot \mathrm{OH}+\cdot \mathrm{H} \text { (pyrolysis) } \\
& \cdot \mathrm{OH}+\cdot \mathrm{H} \rightarrow \mathrm{H}_{2} \mathrm{O} \\
& 2 \cdot \mathrm{OH} \rightarrow \mathrm{H}_{2}+\mathrm{O}_{2} \\
& 2 \cdot \mathrm{OH} \rightarrow \mathrm{H}_{2} \mathrm{O}_{2} \\
& 2 \cdot \mathrm{H} \rightarrow \mathrm{H}_{2}
\end{aligned}
$$

Another widely used AOP is Fenton reaction processes utilizing $\mathrm{Fe}^{+2}$ salts to activate $\mathrm{H}_{2} \mathrm{O}_{2}$ (Dewil et al., 2005). In the Fenton process, the reaction between dissolved $\mathrm{Fe}^{2+}$ and $\mathrm{H}_{2} \mathrm{O}_{2}$ in acidic aqueous solution leads to oxidation of $\mathrm{Fe}^{2+}$ to $\mathrm{Fe}^{3+}$ and formation of the highly reactive $\cdot \mathrm{OH}$

$$
\begin{aligned}
& \mathrm{Fe}^{2+}+\mathrm{H}_{2} \mathrm{O}_{2} \rightarrow \mathrm{Fe}^{3+}+\bullet \mathrm{OH}+\mathrm{OH}^{-} \text {(chain initiation) } \\
& \mathrm{k}_{1} \approx 70 \mathrm{M}^{-1} \mathrm{~s}^{-1}(\mathrm{Rigg} \text { et al., 1954) } \\
& \bullet \mathrm{OH}+\mathrm{Fe}^{2+} \rightarrow \mathrm{OH}-+\mathrm{Fe}^{+3} \text { (chain termination) } \\
& \mathrm{k}_{2} \approx 3.2 \times 10^{8} \mathrm{M}^{-1} \mathrm{~s}^{-1} \text { (Buxton et al., 1988) } \\
& \bullet \mathrm{OH}+\mathrm{H}_{2} \mathrm{O}_{2} \rightarrow \mathrm{H}_{2} \mathrm{O}+\mathrm{HO}_{2} \bullet \\
& \mathrm{k}_{6} \approx 3.3 \times 107 \mathrm{M}^{-1} \mathrm{~s}^{-1} \text { (Buxton and Greenstock, 1988) }
\end{aligned}
$$


As seen in the reactions (6) and (8), $\mathrm{H}_{2} \mathrm{O}_{2}$ is both an initiator and an $\bullet \mathrm{OH}$ scavenger, particularly when its concentration is high.

Another important class of AOPs is based on the use of ozone. These homogeneous AOPs include single ozonation, ozonation with UV-light and the UVperoxide processes. Single ozonation is an AOP only if the process is operated at highly alkaline $\mathrm{pH}$, at which $\mathrm{O}_{3}$ decomposes to produce $\mathrm{OH}$ radicals. At low $\mathrm{pH}$, however, ozone is in molecular form and reacts selectively through direct electrophilic reactions (Soares et al., 2006). The reaction of ozone with $\mathrm{OH}^{-}$ions is given below (Mandal, 2018):

$$
\begin{aligned}
& \mathrm{OH}^{-} \\
& 2 \mathrm{O}_{3}+\mathrm{H}_{2} \mathrm{O} \rightarrow \cdot \mathrm{OH}+2 \mathrm{O}_{2}+\mathrm{HO}_{2}
\end{aligned}
$$

Generation of $\cdot \mathrm{OH}$ in $\mathrm{O}_{3} / \mathrm{H}_{2} \mathrm{O}_{2}$ and $\mathrm{O}_{3} / \mathrm{UV}$ processes proceed via the interaction of ozone with $\mathrm{H}_{2} \mathrm{O}_{2}$, and the photolysis of ozone, respectively, as presented in Eq (10) and (11). The rate of $\mathrm{H}_{2} \mathrm{O}_{2}$ photolysis in these systems is directly related to the incident power or intensity of light and the dose of $\mathrm{H}_{2} \mathrm{O}_{2}$, while that of organic matter degradation is a function of the quantity of $\mathrm{O}_{3}$ and $\bullet \mathrm{OH}$ available in solution (Muruganandham et al., 2014).

$\mathrm{O}_{3}+\mathrm{H}_{2} \mathrm{O}_{2} \rightarrow \cdot \mathrm{OH}+\mathrm{O}_{2}+\mathrm{HO}_{2}$

$\mathrm{O}_{3}+h v+\mathrm{H}_{2} \mathrm{O} \rightarrow 2 \cdot \mathrm{OH}+\mathrm{O}_{2}$

In $\mathrm{UV} / \mathrm{H}_{2} \mathrm{O}_{2}$ process hydrogen peroxide is activated by UV light and hydroxyl radicals $(\bullet \mathrm{OH})$ are generated by the photolysis of hydrogen peroxide (12). $\mathrm{H}_{2} \mathrm{O}_{2}$ photolysis rate directly depends on the incident power or intensity. In addition, the dosage of $\mathrm{H}_{2} \mathrm{O}_{2}$ needs to be optimized, since excess $\mathrm{H}_{2} \mathrm{O}_{2}$ may scavenge hydroxyl radical.

$$
\mathrm{H}_{2} \mathrm{O}_{2}+\mathrm{hv} \rightarrow 2 \cdot \mathrm{OH}
$$

This study aims to evaluate the efficiency of several AOPs for the degradation of an azo dye. Remazol Brillant Blue R (RBBR) was selected as the model dye. RBBR is known for its resistance to chemical oxidation due to its unique chemical structure (Chang et al., 2009). Sonication, Fenton reaction, and ozone-based AOPs $\left(\mathrm{O}_{3}\right.$, $\mathrm{O}_{3} / \mathrm{UV}, \mathrm{O}_{3} / \mathrm{UV} / \mathrm{H}_{2} \mathrm{O}_{2}$ ) were compared for their efficiency in decolorization and mineralization.

\section{Materials and Methods Materials}

RBBR was obtained from Sigma Aldrich. A stock solution was prepared according to the method described by Garcia-Montano et al (2008). Reagent grade hydrogen peroxide $\left(35 \%\right.$, w/v), and $\mathrm{FeSO}_{4} \cdot 7 \mathrm{H}_{2} \mathrm{O}$ were obtained from Merck and used as Fenton's reagents. Reagent grade $\mathrm{NaOH}$ and $\mathrm{H}_{2} \mathrm{SO}_{4}(1 \mathrm{~N})$ were used for $\mathrm{pH}$ adjustment. The structure and chemical/ physical properties of the compound are as given (Rahmat et al., 2016; Bagchi and Ray, 2015; Rodríguez-Couto, 2011):<smiles>Nc1c(S(=O)(=O)O[Na])cc(Nc2cccc(S(=O)(=O)CCOS(=O)(=O)O[Na])c2)c2c1C(=O)c1ccccc1C2=O</smiles>

MW: $626.54 \mathrm{~g} / \mathrm{mol}$

Emprical formula: $\mathrm{C}_{22} \mathrm{H}_{16} \mathrm{~N}_{2} \mathrm{Na}_{2} \mathrm{O}_{11} \mathrm{~S}_{3}$

pKa: 7.0

Water Solubility: $10 \mathrm{~g} \mathrm{~L}^{-1}$

\section{Experimental Set-Up Sonication}

An ultrasound probe (Bandelin Sonoplus HD2200) emitting ultrasonic waves at $20 \mathrm{kHz}$ was immersed into a $100 \mathrm{~mL}$ glass cell surrounded by a water-cooling jacket to keep the reactor at constant temperature $\left(25 \pm 0.5^{\circ} \mathrm{C}\right)$. The power was adjusted to $30 \%$. The samples were preaerated for $20 \mathrm{~min}$ before sonication.

\section{Fenton Reaction}

$250 \mathrm{~mL}$ of azo dye solutions were acidified to $\mathrm{pH} 3$ by 1 $\mathrm{N} \mathrm{H}_{2} \mathrm{SO}_{4}$. In order to initiate Fenton oxidation reaction, after 20 min pre-aeration $0.1 \mathrm{mM} \mathrm{Fe}{ }^{+2}$, and $\mathrm{H}_{2} \mathrm{O}_{2}$ was added to provide 1:20 Fe: $\mathrm{H}_{2} \mathrm{O}_{2}$ ratio and the samples were mixed (mixing rate $125 \mathrm{rpm}$ ) for $1 \mathrm{~h}$.

\section{Ozonation}

Using an Ozonelab-100 Model generator ozone was generated onsite and $21 \mathrm{mg} / \mathrm{min} \mathrm{O}_{3}$ was applied to 250 $\mathrm{mL}$ solution. The $\mathrm{pH}$ of the solution was adjusted to 11 by $1 \mathrm{~N} \mathrm{NaOH}$.

\section{$\mathrm{O}_{3} / \mathrm{UV}$ and $\mathrm{O}_{3} / \mathrm{UV} / \mathrm{H}_{2} \mathrm{O}_{2}$}

In photolytic experiments, a low-pressure $\mathrm{Hg}$-UV lamp emitting at $254 \mathrm{~nm}$ was used. The $\mathrm{pH}$ of the $2 \mathrm{~L}$ sample solution was adjusted to 11 . The ozone dose was 21 $\mathrm{mg} / \mathrm{min}$. In the $\mathrm{O}_{3} / \mathrm{UV} / \mathrm{H}_{2} \mathrm{O}_{2}$ process, $0.1 \mathrm{mM} \mathrm{H}_{2} \mathrm{O}_{2}$ was added to the solution.

\section{Analytical}

In every experimental set-up, samples were collected at time $\mathrm{t}=0,5,10,20,30$ and $40 \mathrm{~min}$. The $\mathrm{pH}$ of the solution was monitored using a Metler Toledo $\mathrm{pH}$ meter. Mineralization was measured in terms of Total Organic Carbon (TOC) using a Shimadzu TOC-V CSH Analyzer. Color removal was measured spectrophotometrically. The absorbance of the test solutions at $588 \mathrm{~nm}$ was analyzed using a Unicam He $\lambda$ ios Alpha/Beta double beam spectrophotometer. Hydrogen peroxide was measured by measuring absorbance at $351 \mathrm{~nm}$ wavelength. Then the measured absorbance values were converted to concentration values by preparing a standard curve of known hydrogen peroxide concentrations $(10,20,30,40 \mathrm{ppm})$. 


\section{Results and Discussion}

Experiments were conducted in one of the following setups: the sonication setup, the Fenton reaction setup, ozonation $\left(\mathrm{O}_{3}\right)$ setup, ozonation and UV irradiation $\left(\mathrm{O}_{3} / \mathrm{UV}\right)$ setup, and $\mathrm{O}_{3} / \mathrm{UV} / \mathrm{H}_{2} \mathrm{O}_{2}$ set up. The initial concentration of RBBR was 10 ppm in all set-ups. Test samples were prepared by dilution of a stock solution with deionized water. The results of each AOP was given and discussed in this section.

\section{Sonication}

In this set of experiments $20 \mathrm{kHz}$ ultrasound was applied to the dye solution for $40 \mathrm{~min}$. No $\mathrm{pH}$ adjustment was done and the initial (natural) $\mathrm{pH}$ of the solution was 6.67. The collected samples were analyzed for hydrogen peroxide, $\mathrm{pH}, \mathrm{TOC}$, and decolorization. The results of sonication experiments are shown in Figure 1. It is obvious that sonication alone was ineffective in removing RBBR. As shown in Figure 1 (a) the reaction rate of RBRR degradation by single sonolysis was slow $\left(\mathrm{k}=0.0095 \mathrm{~min}^{-1}\right)$. Figure 1 (b) shows that the process was not very efficient for mineralization. After 40-min sonication only $21 \%$ mineralization was achieved.

In homogenous sonochemistry, there are three main reaction sites: the cavitation bubble, the interface between gas bubbles and the surrounding liquid, and the bulk solution (Adewuyi, 2001; Ince et al., 2001). Oxidation reactions in the bulk solution are limited by the number of available, uncombined, free radicals migrated from the collapsing cavities and the interface into the bulk (Ince et al., 2001).

RBBR is a hydrophilic compound with low volatility. Therefore the compound is not expected to migrate towards the bubble or the interfacial region, but rather remain in the bulk solution, where the concentration of - $\mathrm{OH}$ is very low. Moreover, Figure 1 (d) shows an increase in $\mathrm{H}_{2} \mathrm{O}_{2}$ confirming the recombination of the produced $\bullet \mathrm{OH}$ to form $\mathrm{H}_{2} \mathrm{O}_{2}$. A slight decrease in the solution $\mathrm{pH}$ might be due to the formation of acidic byproducts.
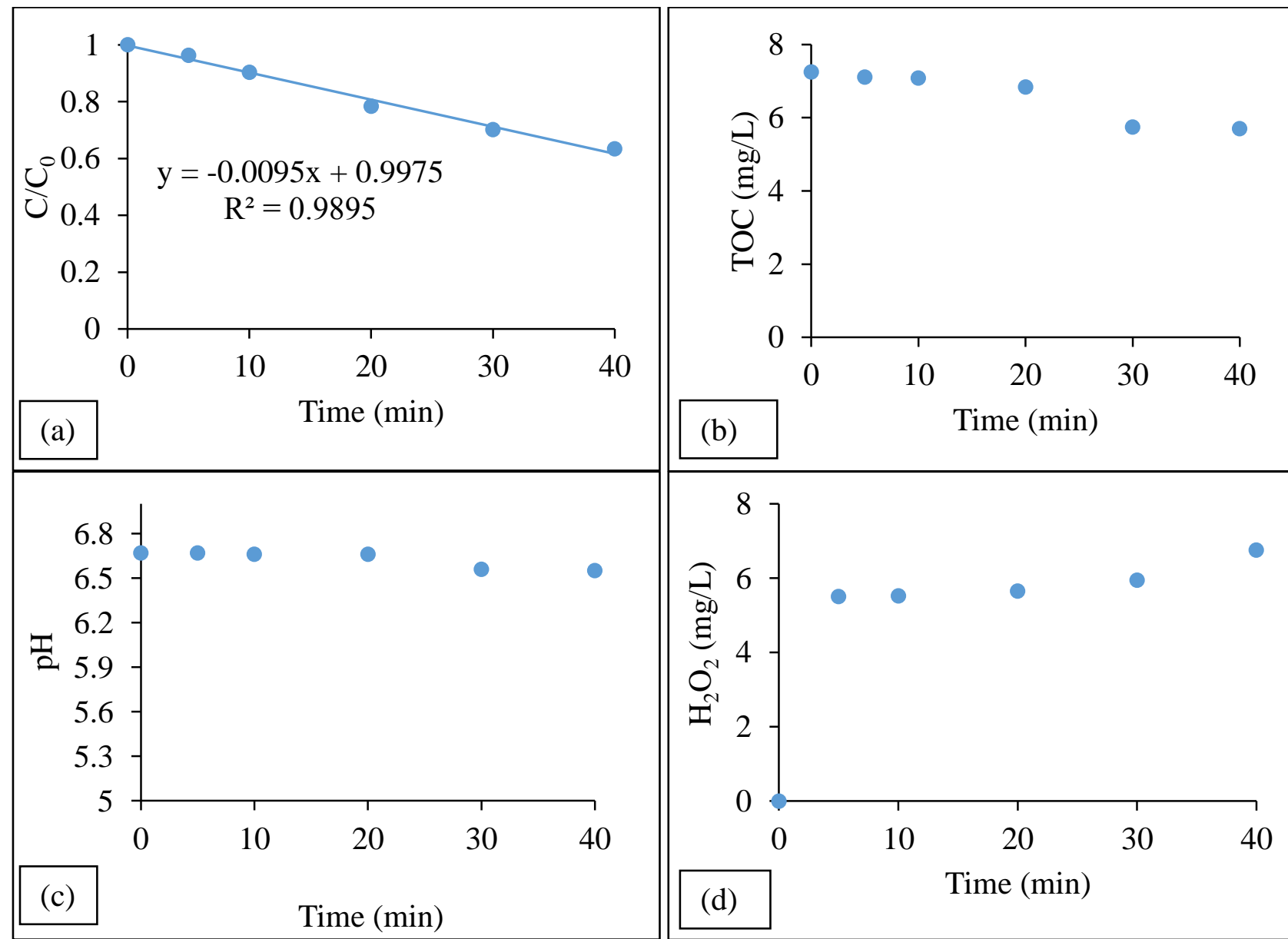

Figure 1. The effect of sonication on (a) degradation of dye, (b) TOC reduction (c) $\mathrm{pH}$ and (d) $\mathrm{H}_{2} \mathrm{O}_{2}$ production.

\section{Fenton Reaction}

The results of the Fenton process are shown in Figure 2. As shown in Figure 2 (a) the degradation of dye was very fast. The process was found to be effective not only for degradation but also for mineralization. At the end of the reaction time (40 $\mathrm{min})$ approximately $60 \%$ mineralization was achieved. We can say from figure 2 (d) that $\mathrm{OH}$ radicals were formed by reaction (6). The constant $\mathrm{pH}$ of the solution indicates that the RBBR was not converted to by-products but more than half of it was efficiently mineralized. However, Fenton's reaction 
alone was not able to completely mineralize the azo dyes as the process is limited by the redox cycle between $\mathrm{Fe}^{2+}$ and $\mathrm{Fe}^{3+}$ (Ameta et al., 2013). According to a review study on dye degradation by Fenton process, Nidheesh et al. (2013), our results are in complete agreement with the literature.

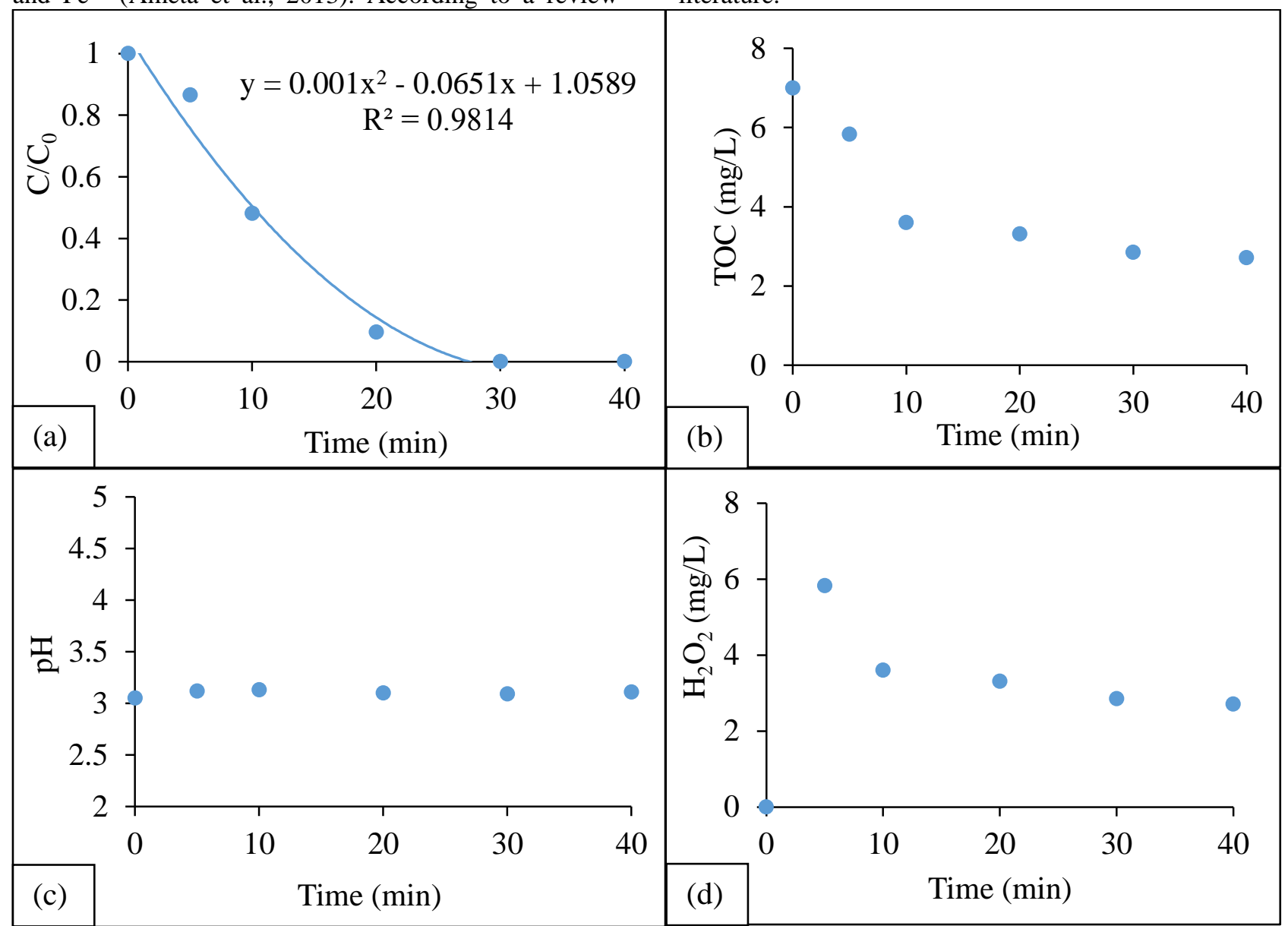

Figure 2. The effect of Fenton reaction on (a) degradation of dye, (b) TOC reduction (c) $\mathrm{pH}$ and (d) $\mathrm{H}_{2} \mathrm{O}_{2}$ production.

\section{Ozonation-Based AOPs $\left(\mathrm{O}_{3}, \mathrm{O}_{3} / \mathrm{UV}, \mathrm{O}_{3} / \mathrm{UV} / \mathrm{H}_{2} \mathrm{O}_{2}\right)$}

For $\mathrm{O}_{3}, \mathrm{O}_{3} / \mathrm{UV}$ and $\mathrm{O}_{3} / \mathrm{UV} / \mathrm{H}_{2} \mathrm{O}_{2}$ processes the pseudofirst-order degradation curves of RBBR and the percentage of mineralization are shown in Fig. 3. The data show that the single ozonation process was inadequate for dye degradation and mineralization. This finding can be explained by the low reactivity of the parent compound, RBBR, as well as its oxidation byproducts with $\mathrm{O}_{3}$.

The combination of ozone with UV irradiation resulted in an enhancement in the reaction rate. Figure 3 (a) shows that by the addition of UV light to the ozone reactor, the reaction rate constant increased from 0.002 $\min ^{-1}$ to $0.02 \mathrm{~min}^{-1}$. In addition, mineralization increased from $14 \%$ to $33 \%$ with the integration of UV irradiation. This synergistic effect between UV light and ozone is in complete agreement with the literature and explained by the production of more hydroxyl radicals than in the case of single ozonation (Cuiping et al. 2011; Cortez et al., 2011).

$\mathrm{O} 3 / \mathrm{UV} / \mathrm{H}_{2} \mathrm{O}_{2}$ process was found to be the most effective AOP between the tested processes. By using this process complete decolorization was achieved in less than 10min reaction time and $83 \%$ mineralization was achieved at the end of 40-min reaction time. The efficiency of this hybrid process is due to the production of $\cdot \mathrm{OH}$ by several individual and combined processes. The efficiency of the process can be attributed to: i) photolysis of the RBBR, ii) generation of $\bullet \mathrm{OH}$ by single ozonation, iii) photolysis of ozone by UV, iv) photolysis of the added $\mathrm{H}_{2} \mathrm{O}_{2}$ by UV, v) the combined effect of $\mathrm{H}_{2} \mathrm{O}_{2}$ and $\mathrm{O}_{3}$.

Relative mineralization of RBBR upon 40-min reaction by all tested AOPs is summarized in Figure 4. It is obvious that RBBR was not completely mineralized in any of these five processes. RBBR mineralization efficiencies were in the decreasing order of Ozonation $/ \mathrm{UV} / \mathrm{H}_{2} \mathrm{O}_{2}>$ Fenton > Ozonation/UV > Ultrasound > Ozone.

\section{Conclusion}

Five AOPs, sonication, Fenton reaction, $\mathrm{O}_{3}, \mathrm{O}_{3} / \mathrm{UV}$, $\mathrm{O}_{3} / \mathrm{UV} / \mathrm{H}_{2} \mathrm{O}_{2}$ were tested for the elimination of a recalcitrant azo dye, RBBR, from water. The least effective AOP was found to be the single ozonation process. However, by combining with UV irradiation and $\mathrm{H}_{2} \mathrm{O}_{2}$, the efficiency of the process was significantly increased. The addition of UV irradiation to single ozonation process provided a $27 \%$ additional mineralization (42\% mineralization). The most effective process was $\mathrm{O}_{3} / \mathrm{UV} / \mathrm{H}_{2} \mathrm{O}_{2}$ due to individual as well as combined effects of $\mathrm{O}_{3}, \mathrm{UV}$ irradiation and $\mathrm{H}_{2} \mathrm{O}_{2}$. 

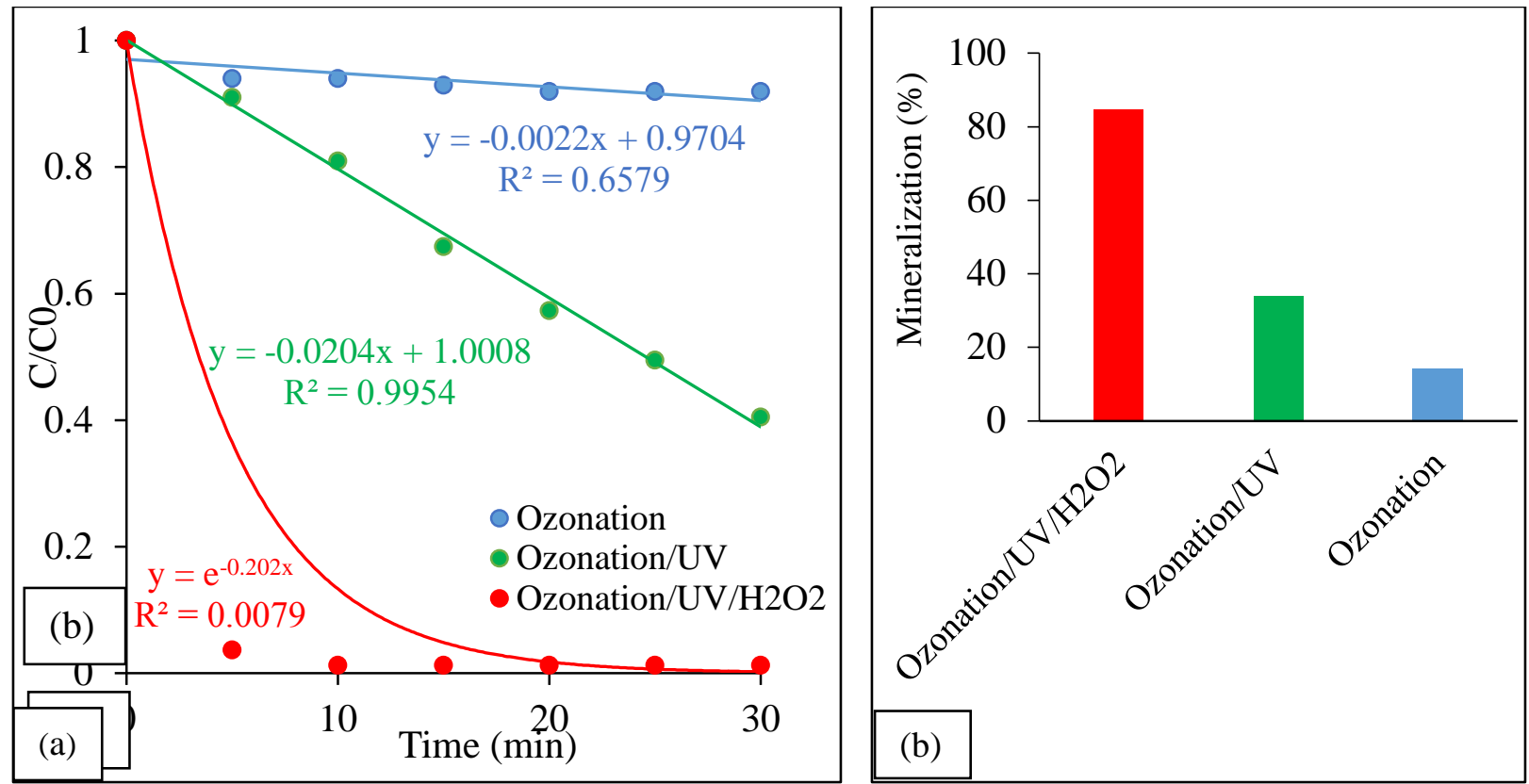

Figure 3. The effect of Ozonation-Based AOPs on (a) dye degradation and (b) mineralizatio

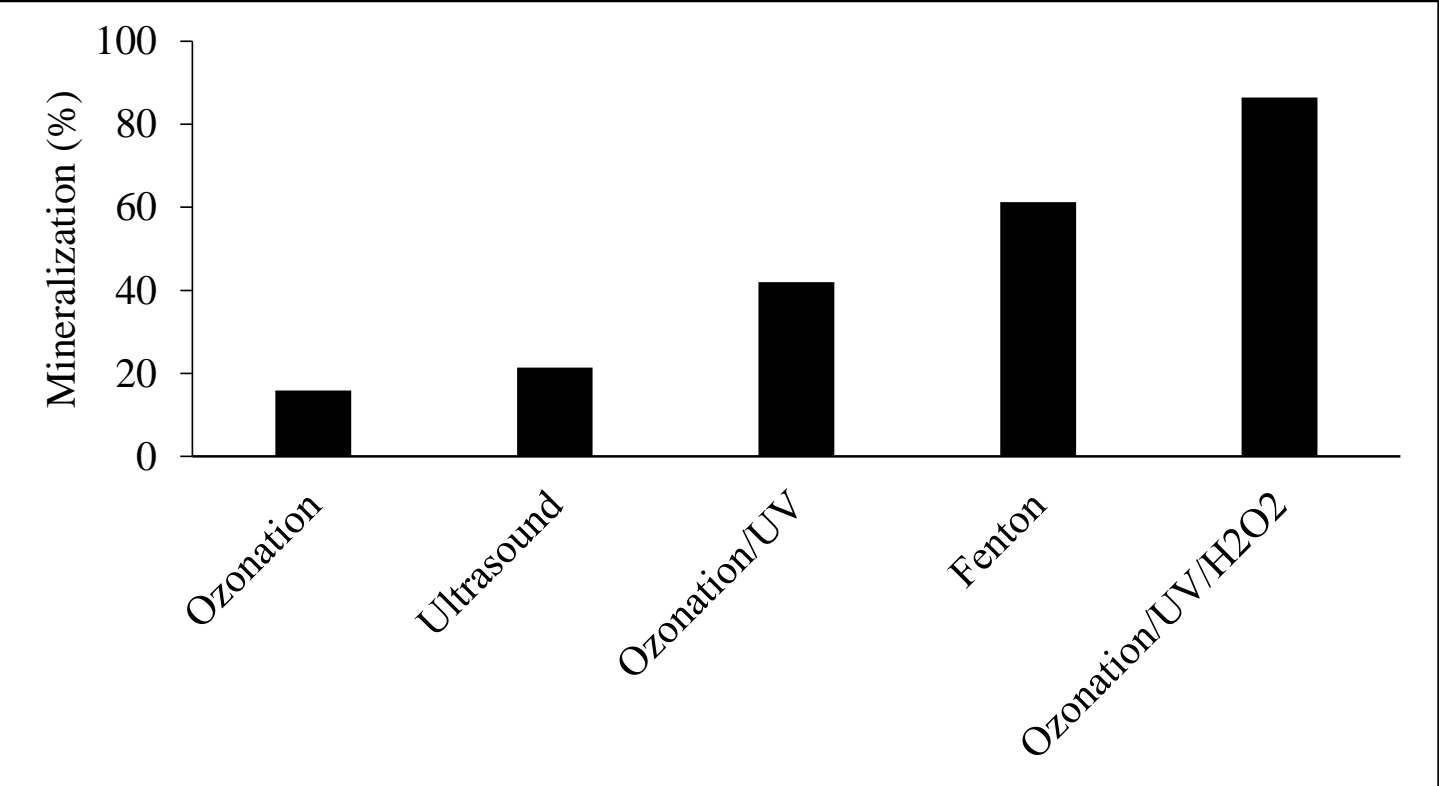

Figure 4. Relative mineralization after 40-min contact with the test AOPs.

It is also demonstrated that the application of ultrasound provided limited mineralization of the azo dye solution. The inefficiency of sonication is attributed to the low volatility of the dye which inhibited its transfer into the cavity bubble. Hence, the reaction took place in the bulk solution where the $\cdot \mathrm{OH}$ concentration is the lowest. Fenton reaction was also found to be the second most effective process. This process provided complete decolorization after the 20-min reaction. However, at the end of the 40 min reaction time, only $62 \%$ mineralization was achieved, indicating the formation of small-weight oxidation byproducts, which were resistant to further decomposition.

Further research is needed to investigate the toxicity of the reaction by-products of the compared processes. Also, an economic analysis on the initial investment costs and operating costs of the AOPs should be conducted to determine the most economical processes.

\section{Acknowledgements}

Başak Savun-Hekimoğlu is a post-doctoral researcher at Istanbul University, Institute of Marine Sciences and Management. The author is thankful to the Istanbul University Research Fund (BAP) for post-doctoral scholarship granted with an identity number MAB-201934967.

\section{References}

Adewuyi, Y. G. (2001). Sonochemistry: environmental science and engineering applications. Industrial \& Engineering Chemistry Research, 40(22), 4681-4715. 
Ameta, R., Benjamin, S., Ameta, A., Ameta, S. C. (2013). Photocatalytic degradation of organic pollutants: a review. In Materials Science Forum (Vol. 734, pp. 247-272). Trans Tech Publications Ltd.

Babu, S. G., Ashokkumar, M., Neppolian, B. (2017). The role of ultrasound on advanced oxidation processes. In Sonochemistry (pp. 117-148). Springer, Cham.

Bagchi, M., Ray, L. (2015). Adsorption behavior of Reactive Blue 4, a tri-azine dye on dry cells of Rhizopus oryzae in a batch system. Chemical Speciation \& Bioavailability, 27(3), 112-120.

Buxton, G. V., Greenstock, C. L., Helman, W. P., Ross, A. B. (1988). Critical review of rate constants for reactions of hydrated electrons, hydrogen atoms and hydroxyl radicals $(\cdot \mathrm{OH} / \cdot \mathrm{O}-$ in aqueous solution. Journal of physical and chemical reference data, 17(2), 513-886.

Chang, S. H., Chuang, S. H., Li, H. C., Liang, H. H., Huang, L. C. (2009). Comparative study on the degradation of IC Remazol Brilliant Blue R and IC Acid Black 1 by Fenton oxidation and Fe0/air process and toxicity evaluation. Journal of Hazardous Materials, 166(2-3), 1279-1288.

Cortez, S., Teixeira, P., Oliveira, R., Mota, M. (2011). Evaluation of Fenton and ozone-based advanced oxidation processes as mature landfill leachate pretreatments. Journal of environmental management, 92(3), 749-755.

Cuiping, B., Xianfeng, X., Wenqi, G., Dexin, F., Mo, X., Zhongxue, G., Nian, X. (2011). Removal of rhodamine $\mathrm{B}$ by ozone-based advanced oxidation process. Desalination, 278(1-3), 84-90.

Dewil, R., Baeyens, J., Neyens, E. (2005). Fenton peroxidation improves the drying performance of waste activated sludge. Journal of hazardous materials, 117(2-3), 161-170.

Fast, S. A., Gude, V. G., Truax, D. D., Martin, J., Magbanua, B. S. (2017). A critical evaluation of advanced oxidation processes for emerging contaminants removal. Environmental Processes, 4(1), 283-302.

Fischer, C. H., Hart, E. J., Henglein, A. (1986). Ultrasonic irradiation of water in the presence of oxygen 18, 1802: isotope exchange and isotopic distribution of hydrogen peroxide. The Journal of Physical Chemistry, 90(9), 1954-1956.

Frontistis, Z., Mantzavinos, D. (2017). Advanced oxidation processes for wastewater treatment. Wastewater and biosolids management, 1st edn. IWA Publishing, London, 131-143.

Ince, N. H., Tezcanli, G., Belen, R. K., Apikyan, İ. G. (2001). Ultrasound as a catalyzer of aqueous reaction systems: the state of the art and environmental applications. Applied Catalysis B: Environmental, 29(3), 167-176.

Krishnan, S., Rawindran, H., Sinnathambi, C. M., Lim, J. W. (2017). Comparison of various advanced oxidation processes used in remediation of industrial wastewater laden with recalcitrant pollutants. In $I O P$ Conf. Ser. Mater. Sci. Eng (Vol. 206, No. 1).

Lorimer, J. P., Mason, T. J., Fiddy, K. (1991). Enhancement of chemical reactivity by power ultrasound: an alternative interpretation of the hot spot. Ultrasonics, 29(4), 338-343.

Mandal, S. (2018). Reaction rate constants of hydroxyl radicals with micropollutants and their significance in advanced oxidation processes. Journal of Advanced Oxidation Technologies, 21(1), 178-195.

Mason, T. J., Lorimer, J. P., Walton, D. J. (1990). Sonoelectrochemistry. Ultrasonics, 28(5), 333-337.

Mason, T. J., Peters, D. (2002). Practical sonochemistry: Power ultrasound uses and applications. Woodhead Publishing.

Miklos, D. B., Remy, C., Jekel, M., Linden, K. G., Drewes, J. E., Hübner, U. (2018). Evaluation of advanced oxidation processes for water and wastewater treatment-A critical review. Water research, 139, 118-131.

Muruganandham, M., Suri, R. P. S., Jafari, S., Sillanpää, M., Lee, G. J., Wu, J. J., Swaminathan, M. (2014). Recent developments in homogeneous advanced oxidation processes for water and wastewater treatment. International Journal of Photoenergy, 2014.

Muruganandham, M., Suri, R. P., Sillanpää, M., Wu, J. J., Ahmmad, B., Balachandran, S., Swaminathan, M. (2014). Recent developments in heterogeneous catalyzed environmental remediation processes. Journal of Nanoscience and Nanotechnology, 14(2), 1898-1910.

Nidheesh, P. V., Gandhimathi, R.,Ramesh, S. T. (2013). Degradation of dyes from aqueous solution by Fenton processes: a review. Environmental Science and Pollution Research, 20(4), 2099-2132.

Peters, D. (1996). Ultrasound in materials chemistry. Journal of materials chemistry, 6(10), 1605-1618.

Rahmat, N. A., Ali, A. A., Hussain, N., Muhamad, M. S., Kristanti, R. A., Hadibarata, T. (2016). Removal of Remazol Brilliant Blue $\mathrm{R}$ from aqueous solution by adsorption using pineapple leaf powder and lime peel powder. Water, Air, \& Soil Pollution, 227(4), 105.

Rigg, T., Taylor, W., Weiss, J. (1954). The rate constant of the reaction between hydrogen peroxide and ferrous ions. The journal of chemical physics, 22(4), 575-577.

Rodríguez-Couto, S. (2011). Production of laccase and decolouration of the textile dye Remazol Brilliant Blue $\mathrm{R}$ in temporary immersion bioreactors. Journal of hazardous materials, 194, 297-302.

Soares, O. S. G., Orfao, J. J., Portela, D., Vieira, A., Pereira, M. F. R. (2006). Ozonation of textile effluents and dye solutions under continuous operation: Influence of operating parameters. Journal of Hazardous Materials, 137(3), 1664-1673.

Suslick, K. S. (1990). Sonochemistry. Science, 247(4949), 1439-1445. 